\title{
Article \\ Combined Effects of Temperature and Salinity on Polyps and Ephyrae of Aurelia solida (Cnidaria: Scyphozoa)
}

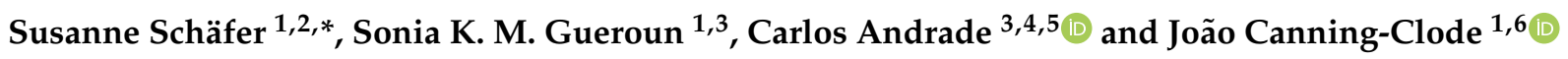 \\ 1 MARE-Marine and Environmental Sciences Centre, Agência Regional para o Desenvolvimento \\ da Investigação, Tecnologia e Inovação (ARDITI), 9020-105 Funchal, Madeira, Portugal; \\ sgueroun@mare-centre.pt (S.K.M.G.); jcanning-clode@mare-centre.pt (J.C.-C.) \\ 2 GEOMAR Helmholtz Centre for Ocean Research Kiel, 24105 Kiel, Germany \\ 3 Mariculture Centre of Calheta, 9370-133 Calheta, Madeira, Portugal; carlos.a.andrade@madeira.gov.pt \\ 4 OOM-Madeira Oceanic Observatory, 9020-105 Funchal, Madeira, Portugal \\ 5 CIIMAR/CIMAR-Interdisciplinary Centre of Marine and Environmental Research, University of Porto, \\ 4450-208 Matosinhos, Portugal \\ 6 Smithsonian Environmental Research Center, Edgewater, MD 21037, USA \\ * Correspondence: sschaefer@mare-centre.pt
}

Citation: Schäfer, S.; Gueroun,

S.K.M.; Andrade, C.; Canning-Clode, J. Combined Effects of Temperature and Salinity on Polyps and Ephyrae of Aurelia solida (Cnidaria:

Scyphozoa). Diversity 2021, 13, 573. https://doi.org/10.3390/d13110573

Academic Editor: Bert W. Hoeksema

Received: 29 September 2021

Accepted: 4 November 2021

Published: 10 November 2021

Publisher's Note: MDPI stays neutral with regard to jurisdictional claims in published maps and institutional affiliations.

Copyright: (c) 2021 by the authors. Licensee MDPI, Basel, Switzerland. This article is an open access article distributed under the terms and conditions of the Creative Commons Attribution (CC BY) license (https:// creativecommons.org/licenses/by/ $4.0 /)$.

\begin{abstract}
Jellyfish outbreaks are conspicuous natural events in marine ecosystems that have a substantial impact on the structure and dynamics of marine ecosystems and different economic sectors of human activities. Understanding the life cycle strategies of jellyfish species is therefore critical to mitigate the impacts these organisms may have. In this context, the present study investigated the effect of different temperature and salinity regimes on the rearing success of the jellyfish Aurelia solida in microcosm experiments on two different life stages: polyps and ephyrae. Polyps showed high survival rates across the different conditions (except at $28^{\circ} \mathrm{C} / 20 \mathrm{psu}$ ) and reproduced asexually in all combinations, with the highest budding activity at $20^{\circ} \mathrm{C}$ and $30 \mathrm{psu}$. Strobilation occurred mainly at $16^{\circ} \mathrm{C}$ and $35 \mathrm{psu}$. Although ephyra survival was highest at low salinities (20 psu) and lower temperatures $\left(10\right.$ and $\left.15{ }^{\circ} \mathrm{C}\right)$, the highest growth rates were reached at intermediate temperatures $\left(20^{\circ} \mathrm{C}\right)$. The comparison to other Aurelia species underlines the differences between even closely related species. Given the high tolerance capacity that $A$. solida presented in the experiments, the species has the potential to cope well under current climate change scenarios and possibly adapt successfully to other regions and ecosystems.
\end{abstract}

Keywords: jellyfish; multiple stressors; survival; asexual reproduction; strobilation; somatic growth; microcosm experiment

\section{Introduction}

Jellyfish have manifold impacts on marine ecosystems and human society [1]. They play an essential role in the marine food web as predators [2] and prey [3,4]. Therefore, their densities can lead to significant changes in local trophic webs and the structure and function of ecosystems [5-7].

Scyphozoan blooms can affect human society and the economy [8] in several ways, including aquaculture and fisheries (e.g., damaging caught/farmed fish and increasing mortality in farmed fish) [9], tourism [10,11], and industry (e.g., clogging the cooling systems of coastal power plants) $[12,13]$. While scyphozoan blooms have mainly been associated with negative consequences, several studies have focused on the potential of these gelatinous organisms as a new blue resource (e.g., human and aquaculture food source, cosmetics, biomedical industry) [14-16].

It is critical to understand processes such as reproduction and survival that drive scyphozoan populations, in order to assess, forecast, and mitigate those impacts and evaluate their sustainability as a new resource. Most scyphozoans have a complex bipartite 
life cycle: (i) a pelagic medusa stage that typically reproduces sexually, producing a freeswimming planula, and (ii) a sessile polyp. Polyps reproduce asexually through various budding modes (e.g., budding from stolon, lateral budding, motile bud-like tissue particles), podocysts, and strobilation [17]. The propagation strategies vary among scyphozoans. Some species adapt one mode (mono-mode) (e.g., podocysts in Rhizostoma luteum [18]) while other scyphozoans use two or more strategies, as observed in Aurelia spp. (e.g., lateral budding, lateral budding through stolons, reproduction from parts of stolons/stalks, podocysts, and motile bud-like tissue particles) [19]. Environmental factors (e.g., temperature, salinity, food supply) influence both polyp (e.g., asexual reproduction: intensity, timing, preferred budding mode) [20] and medusa ecology (e.g., somatic growth, sexual maturation) [21]. The responses to the various factors are species-specific. For instance, a temperature rise induces a decline in polyp survival in Cyanea capillata but an increase in Chrysaora hysoscella [22]. This diversity of responses can also be observed in the same genus. In the Aurelia genus, strobilation is boosted at high temperatures in A. labiata [23] but absent in A. aurita when temperatures exceed $4{ }^{\circ} \mathrm{C}$ [22]. Therefore, understanding the influence of abiotic factors on reproduction is vital to make predictions on the species' future under ongoing environmental changes/climate change and possibilities of further spread.

For several decades, studies have highlighted the extensive geographical distribution of A. aurita and its tolerance to very different environmental conditions, until the molecular analysis performed by Dawson and Jacobs [24] unmasked the species diversity of the genus Aurelia. Thereafter, the extraordinary plasticity of $A$. aurita s.l. needed to be reconsidered, and previous studies on $A$. aurita s.l. should be regarded with caution. The distribution of $A$. aurita has been limited to the North Atlantic, the Baltic Sea, the Black Sea, and the Bosphorus Strait [24]. A study on A. aurita s.l. in the Mediterranean revealed the presence of at least three different Aurelia species in the area: A. coerulea, A. relicta, and A. solida [25].

Aurelia solida has been described as native to the Indian Ocean (Maldive Islands: type locality) and the Red Sea and non-indigenous in the Mediterranean [25]. Furthermore, there are records of the species in the Northeast Atlantic (e.g., Azores, Madeira) [26,27]. Even though A. solida is considered non-indigenous in the Mediterranean Sea, the history of its introduction to the NE Adriatic Sea, Ionian Sea, and Northern Tunisia is still unknown. As the species has only been recently identified as A. solida [25], genetic analysis on old samples and more studies are needed to potentially identify its introduction period in the Mediterranean Sea, disentangle the species ecology, and evaluate its potential invasiveness.

Aurelia solida is primarily found in fully marine environments but is also recorded in coastal lagoons [28]. Therefore, their distribution covers a wide range of abiotic parameters, with temperature ranging from 8 to $31^{\circ} \mathrm{C}$ (Tunisia: $11-28.4{ }^{\circ} \mathrm{C}$, Northern Adriatic: $8-\sim 25^{\circ} \mathrm{C}$, Red Sea: $15-31{ }^{\circ} \mathrm{C}$ ) [28-30] and salinities from 20 to 40 psu (Tunisia: $20-40 \mathrm{psu}$, Adriatic: $\sim 32-37.5 \mathrm{psu}$ [30-32]). As A. solida is recorded in areas with very different abiotic conditions, it is a great candidate to study physiological plasticity at different life stages. In this context, the present study was developed to evaluate $A$. solida performance and reproduction success across its distributional range.

\section{Materials and Methods}

\subsection{Polyp Culture}

Polyps were grown from asexual reproduction from specimens originating from the Piran Habour, Adriatic Sea, provided by the Zoo Vienna in 2018. The polyp culture was kept at the Mariculture Center facility (Madeira Island) and maintained in $12 \mathrm{~L}$ aquariums filled with UV-filtered seawater ( 10 microns, $35 \mathrm{psu})$ at ambient temperatures $\left(18-25^{\circ} \mathrm{C}\right.$ over the seasons) with a 12:12 light cycle. They were fed with newly hatched $(<24 \mathrm{~h})$ Artemia fransiscana (Inve Aquaculture $\mathrm{NV}^{\circledR}$, Dendermonde, Belgium) twice a week.

Extra care was taken to ensure that no individuals were released into the wild. Polyp culture and the experiments were performed in fully closed systems that were physically separated from any outgoing drainage systems. Additionally, polyp and ephyra experiments were conducted in freshwater temperature baths. Any seawater and equipment 
used for the culture and experiment were bleached and afterward passed to the public waste treatment system.

\subsection{Temperature-Salinity Experiment on Polyps}

A microcosm experiment was performed in the MOSS (Marine Organism Stress Simulator) and laboratory facilities at the Madeira research unit of MARE (Marine and Environmental Research Centre), located at Quinta do Lorde Marina, from March to June 2019. The experiment investigated the simultaneous effects of temperature and salinity on the survival and asexual reproduction of $A$. solida polyps (Figure 1). Two orthogonal treatment sets were established with five different temperatures $\left(12,16,20,24\right.$, and $\left.28{ }^{\circ} \mathrm{C}\right)$ and six different salinities $(20,25,30,35,37$, and $40 \mathrm{psu})$ reflecting conditions recorded in the different environments where $A$. solida has been recorded. A 37-psu salinity treatment was included in the study to reflect the locations of current $A$. solida populations (average salinity in the surface layer of the Mediterranean Sea and in the Bizerte Lagoon) [33-35]. Each of the 30 combinations was tested with twelve polyps.

Experiments: Optimum temperature and salinity

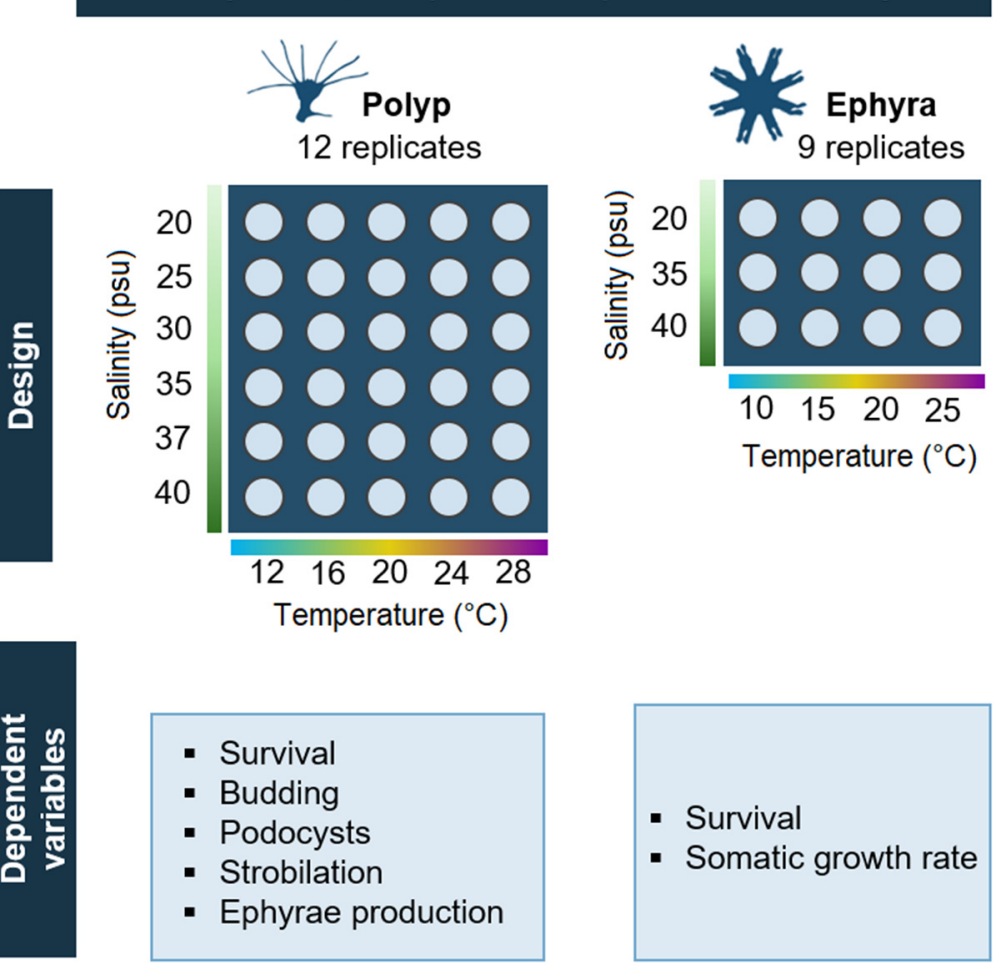

Figure 1. Study design and dependent variables for the optimum temperature and salinity experiments on Aurelia solida polyps and ephyrae.

Polyps were kept individually in jars with $100 \mathrm{~mL}$ filtered $\left(0.7 \mu \mathrm{m}, \mathrm{GF} / \mathrm{F}\right.$ Whatman $\left.{ }^{\circledR}\right)$ seawater. Water baths were used to maintain the designed temperatures. The different salinities were adjusted by the addition of distilled water (salinity $<35 \mathrm{psu}$ ) or aquarium salt (salinity $>35 \mathrm{psu}$ ). The photoperiod was maintained at $12 \mathrm{~h}$ light: $12 \mathrm{~h}$ dark.

Polyps were acclimated to target conditions for nine days prior to the experiment. During the experiment, polyps were fed in excess twice a week for a period of $1.5 \mathrm{~h}$, followed by a complete water change to remove remaining food and waste products. This feeding protocol enabled the polyps to be saturated briefly, resulting in equal feeding in all treatments by minimizing enhanced feeding at warmer temperatures [36].

Over eight weeks, polyp survival and asexual reproduction were checked twice a week. For this purpose, polyps were inspected under stereo microscopes (S8APO and EZ4, Leica ${ }^{\circledR}$, Wetzlar, Germany) twice a week. Buds, new polyps, and podocysts were recorded 
before being carefully removed with a scalpel. After the first part of the experiment (eight weeks), the polyps were kept for an additional six weeks at the same conditions but undisturbed (no removal of reproduction output) to follow the strobilation onset and following ephyra production.

\subsection{Temperature-Salinity Experiment on Ephyrae}

In November and December 2020, an experiment was performed to investigate the combined effects of temperature and salinity on the survival and somatic growth of $A$. solida ephyrae (Figure 1). Polyps, extracted from the broodstock, underwent strobilation under indomethacin $(50 \mu \mathrm{M})$ stimulation following the protocol of Helm and Dunn [37]. Polyps were kept unfed during the process, and released ephyrae were separated and washed three times to eliminate potential rests of indomethacin before using them in any experiment. Two orthogonal treatment sets were established with four different temperatures $(10,15,20$, and $\left.25^{\circ} \mathrm{C}\right)$ and three different salinities $(20,35$, and $40 \mathrm{psu})$ reflecting conditions recorded in the different environments where $A$. solida ephyrae have been recorded. Nine ephyrae were used for each treatment combination. Ephyrae were stepwise acclimatized to their target temperatures and salinities for three days $\left(\leq 5^{\circ} \mathrm{C}\right.$ and $\leq 5 \mathrm{psu}$ per day). The setup followed the same design as described in the polyp experiment. Additionally, an aeration tube with gentle bubbling was added to each jar to ensure water movement, which is critical for ephyra wellbeing.

Each day, the ephyrae were checked for survival, the water was filtered to remove excess food and waste products, and then the ephyrae were fed with newly hatched Artemia. Twice a week, the water was replaced completely and the ephyrae were photographed in a relaxed state using a Leica S8AP0 stereomicroscope equipped with a Leica MC170 HD camera to monitor their growth. Ephyra size was defined as the distance between opposite lappet tips and measured using the software ImageJ [38].

\subsection{Statistical Analysis}

The effect of different temperatures and salinities on polyp and ephyra survival was analyzed using Cox Proportional-Hazard models (Coxph, R packages: "survival" and "survminer") [39,40]. The assumption of proportional hazards was tested with the global test statistic.

Count data for asexual reproduction were analyzed statistically with a generalized linear mixed model (GLMM) with a negative binomial distribution ( $\mathrm{R}$ packages "gglmTMB", "tidyr", and "bbmle") [41-43], including the two factors "Temperature" (5 levels: 12, 16, 20, 24, and $28^{\circ} \mathrm{C}$ ) and "Salinity" (6 levels: 20, 25, 30, 35, 37, and $40 \mathrm{psu}$ ). The factor "Sampling Event" was included as a random factor to account for repeated measures throughout the experiment, and the numbers of alive polyps and days between samplings were used as an offset to standardize for unequal sampling efforts between sampling events. Assumptions of the glmm were verified graphically using diagnostic plots.

Differences in overall ephyra growth were analyzed as the relative change in diameter over the 21 days of the experiment. Furthermore, weekly growth rates were calculated as the diameter change (in \%) between the beginning and end of each week. By the end of the study, only a single ephyra survived in all of the $25^{\circ} \mathrm{C}$ treatment groups and was consequently excluded from the statistical analysis. The remaining groups were analyzed using analysis of variance (Anova). Assumptions were checked with Levene's test for homogeneity of variance and a Shapiro-Wilk test for normality; significant results were further tested by a post hoc Tukey test.

All statistical data analyses were performed with the software R 3.6.3 [44]. Statistically significant differences of the Coxph, GLMM, and Anova were identified with the Anova function (R package "car") [45] using the Wald chi-square test (type III in case of significant interactions, type II when interactions were not significant). In the case of non-significant interactions, the models were simplified and only the main effects were analyzed. In the case of significant interactions, the main effects were not analyzed independently and post- 
hoc analyses on differences in means were performed using multiple pairwise comparisons (R package "emmeans") [46].

\section{Results}

\subsection{Polyp Survival and Asexual Reproduction}

Polyp survival was generally high; only the combination of the highest temperature and lowest salinity $\left(28^{\circ} \mathrm{C}\right.$ and $20 \mathrm{psu}$ ) resulted in $0 \%$ survival (Figure 2). All other treatment combinations showed survival rates between 83 and 100\%. Coxph analysis showed that polyp survival did not vary significantly between treatments for temperatures or salinities; however, an interaction between temperature and salinity was detected (Table 1).

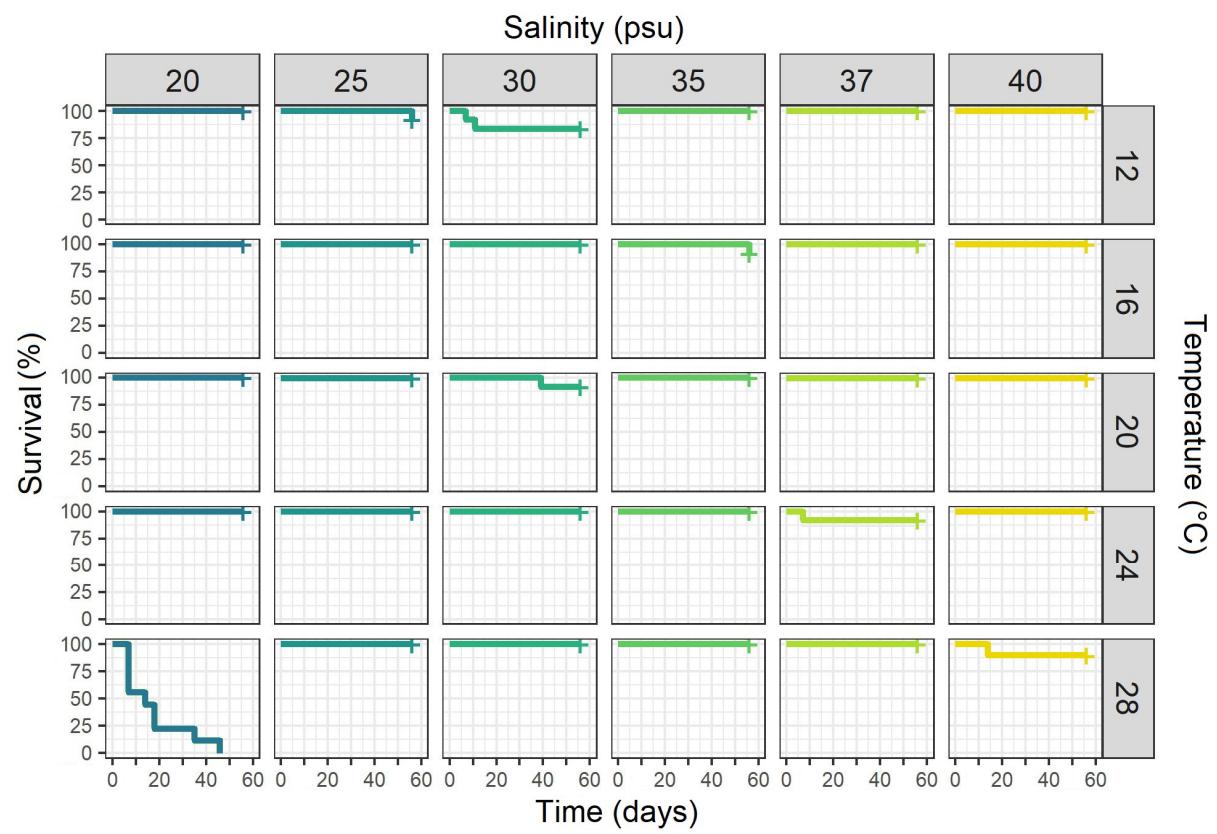

Figure 2. Kaplan-Meier survival curves for Aurelia solida polyps kept at 30 different combinations of temperatures and salinities over 56 days of the experiment ( $n=12$ per combination).

Table 1. Statistical analysis for several variables measured on Aurelia solida kept under different temperatures and salinities. Results for polyp survival, polyp asexual reproduction, and ephyra survival are presented as the output of chi-squared tests $\left(\mathbf{X}^{2}\right)$; those for ephyra growth as Anova output (F-statistic). Significant results $(p<0.05)$ are highlighted in bold.

\begin{tabular}{ccccccc}
\hline \multirow{2}{*}{ Variable Tested } & \multicolumn{2}{c}{ Temperature $\left({ }^{\circ} \mathbf{C}\right)$} & \multicolumn{2}{c}{ Salinity $(\mathbf{p s u})$} & \multicolumn{2}{c}{ Temperature $\times$ Salinity } \\
& Test Statistic & $p$-Value & Test Statistic & $p$-Value & Test Statistic & $p$-Value \\
\hline Polyp survival & $\mathbf{X}^{2}=03.23$ & 0.520 & $\mathbf{X}^{2}=03.64$ & 0.603 & $\mathbf{X}^{2}=43.34$ & $\mathbf{0 . 0 0 2}$ \\
Asexual reproduction & $\mathbf{X}^{2}=87.14$ & $<\mathbf{0 . 0 0 1}$ & $\mathbf{X}^{2}=42.86$ & $<\mathbf{0 . 0 0 1}$ & $\mathbf{X}^{2}=49.67$ & $<\mathbf{0 . 0 0 1}$ \\
Ephyra survival & $\mathbf{X}^{2}=25.43$ & $<\mathbf{0 . 0 0 1}$ & $\mathbf{X}^{2}=11.35$ & $\mathbf{0 . 0 0 3}$ & $\mathbf{X}^{2}=7.047$ & 0.317 \\
Ephyra growth & $\mathrm{F}=46.82$ & $<\mathbf{0 . 0 0 1}$ & $\mathrm{F}=0.28$ & 0.761 & $\mathrm{~F}=7.69$ & $<\mathbf{0 . 0 0 1}$ \\
\hline
\end{tabular}

Polyps showed asexual reproduction in all "survivable" conditions. A. solida polyps reproduced via budding, podocyst production, and strobilation during the experiment. Podocyst production was low in all combinations, and lateral budding was the most abundant form of asexual reproduction across all the combinations. The total asexual reproduction output of $A$. solida was significantly different between temperatures, salinities, and their interaction ( $p<0.001$, Figure 3, Table 1 and Supplementary Table S1). Overall, podocyst production was low, contributing only $2.7 \%$ of the total asexual reproduction output. The highest production did not exceed 0.005 podocysts per polyp per day $\left(24{ }^{\circ} \mathrm{C} / 25 \mathrm{psu}\right)$, while no podocysts were recorded for the $12{ }^{\circ} \mathrm{C} / 25-30-37 \mathrm{psu}$ and $28^{\circ} \mathrm{C} / 20$ psu treatments. Asexual reproduction mainly occurred via budding. The bud- 
ding rate varied from 0.01 buds per polyp per day for the treatment $28^{\circ} \mathrm{C} / 20$ psu up to 0.89 for $20^{\circ} \mathrm{C} / 30 \mathrm{psu}$. The highest overall reproduction of buds and podocysts together ( 0.91 offspring/polyp/day) occurred at temperatures of $20^{\circ} \mathrm{C}$ and salinities of $30 \mathrm{psu}$ and their combination; below or above these values, reproduction decreased (Figure 3).

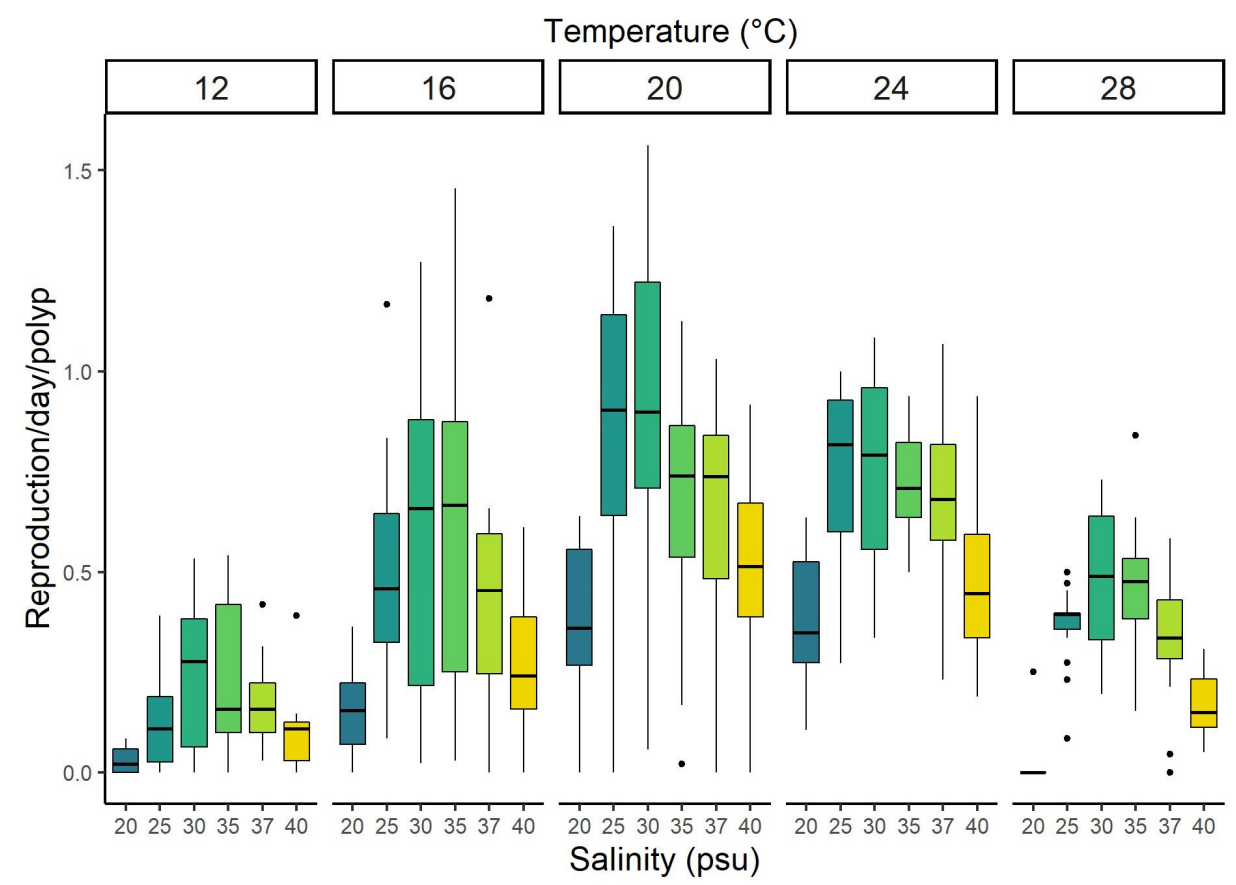

Figure 3. Asexual reproduction output (budding and podocysts combined) of Aurelia solida polyps kept at 30 different combinations of temperatures and salinities over 56 days of the experiment $(n=12$ per combination). Values are standardized by the number of polyps and days and presented as boxplots including quartiles (box and whiskers), median (horizontal line), and outliers (points).

Over the 98 days of the experiment, only nine polyps underwent strobilation (Table 2). Only one strobile was observed in the $12{ }^{\circ} \mathrm{C} / 40 \mathrm{psu}, 16{ }^{\circ} \mathrm{C} / 20 \mathrm{psu}$, and $16{ }^{\circ} \mathrm{C} / 25 \mathrm{psu}$ treatments. The remaining six strobiles occurred at $16^{\circ} \mathrm{C} / 35 \mathrm{psu}$. In this last combination, $50 \%$ of all polyps started strobilation during the experimental period. Strobilation onset occurred on average after $85 \pm 5.1$ days into the experiment and lasted $13.7 \pm 1.5$ days. A few ephyrae were produced at $12{ }^{\circ} \mathrm{C} / 40 \mathrm{psu}\left(5\right.$ ephyrae) and $16{ }^{\circ} \mathrm{C} / 20 \mathrm{psu}$ (10 ephyrae), although most of them were deformed (missing lappets or stuck together). The only strobile at $16^{\circ} \mathrm{C} / 25$ psu produced 29 normal ephyrae with eight lappets. Strobiles at $16^{\circ} \mathrm{C} / 35 \mathrm{psu}$ produced on average $28 \pm 3.6$ ephyrae. Polyps kept at $20^{\circ} \mathrm{C}$ or higher did not show any sign of strobilation throughout the 14 weeks of observation.

Table 2. Data shows combinations of temperatures and salinities that resulted in strobilation in Aurelia solida polyps, including durations until the first and last ephyra were released, the number of released ephyrae per polyp, and comments on the state of released ephyrae.

\begin{tabular}{cccccc}
\hline $\begin{array}{c}\text { Temperature } \\
\left({ }^{\circ} \mathbf{C}\right)\end{array}$ & $\begin{array}{c}\text { Salinity } \\
(\mathbf{p s u})\end{array}$ & $\begin{array}{c}\text { Duration until } \\
\text { First Ephyra } \\
\text { (Days) }\end{array}$ & $\begin{array}{c}\text { Duration from } \\
\text { First to Last } \\
\text { Ephyra (Days) }\end{array}$ & $\begin{array}{c}\text { Number of } \\
\text { Released } \\
\text { Ephyrae (per Polyp) }\end{array}$ & Comment \\
\hline 12 & 40 & 71 & 5 & 5 & deformed ephyrae \\
16 & 20 & 66 & 17 & 29 & $\begin{array}{c}\text { deformed ephyrae } \\
- \\
16\end{array}$ \\
& 25 & 75 & 16 & $28 \pm 3.6(n=3)$ & $\begin{array}{c}\text { not all polyps finished } \\
\text { strobilation during } \\
\text { the experiment }\end{array}$ \\
\hline
\end{tabular}




\subsection{Ephyra Survival and Somatic Growth}

At the end of the experiment, survival ranged from 0 to $66.6 \%$ (Figure 4). Coxph analysis showed that the interaction of temperature and salinity was non-significant $(p=0.32)$ and was consequently removed from the analysis. Ephyrae kept at $15^{\circ} \mathrm{C}$ demonstrated the highest survival rate (52\%). Higher hazard ratios were detected for individuals at $10^{\circ} \mathrm{C}$ (10\% higher) and $20^{\circ} \mathrm{C}(90 \%$ higher), but the difference was not significant $(p=0.84$ and $p=0.07$, Figure 5). Ephyrae at $25^{\circ} \mathrm{C}$ showed a significant fivefold higher risk of mortality compared to $15^{\circ} \mathrm{C}(p<0.001)$. Ephyra survival was highest at a salinity of 20 psu and decreased towards $35 \mathrm{psu}$, but the difference was not significant $(p=0.07)$. The higher salinity of 40 psu increased the hazard of dying significantly by almost threefold $(p<0.001)$.

The ephyrae had an average size of $2.1 \mathrm{~mm} \pm 0.3 \mathrm{~mm}$ at the start of the experiment. Changes in ephyra size varied between the different combinations of temperatures and salinities (Figure 6). Ephyrae kept at temperatures of $10^{\circ} \mathrm{C}$ (all salinities) and the combinations of $20^{\circ} \mathrm{C} / 40$ psu and $25^{\circ} \mathrm{C} / 35-40$ psu showed negative or meager growth rates throughout the experiment (growth rates from -24 to $28 \%$ per week). Ephyrae at $15{ }^{\circ} \mathrm{C}$ (all salinities) and the combinations of $20^{\circ} \mathrm{C} / 20-35$ psu constantly increased their size throughout the experiment (growth rates of 20 to $118 \%$ per week). Ephyrae at $25^{\circ} \mathrm{C} / 20 \mathrm{psu}$ showed an increase in size over the first two weeks (growth rates from 10 up to $54 \%$ per week) but decreased in the third week of the experiment (growth rate of $-23 \%$ per week).

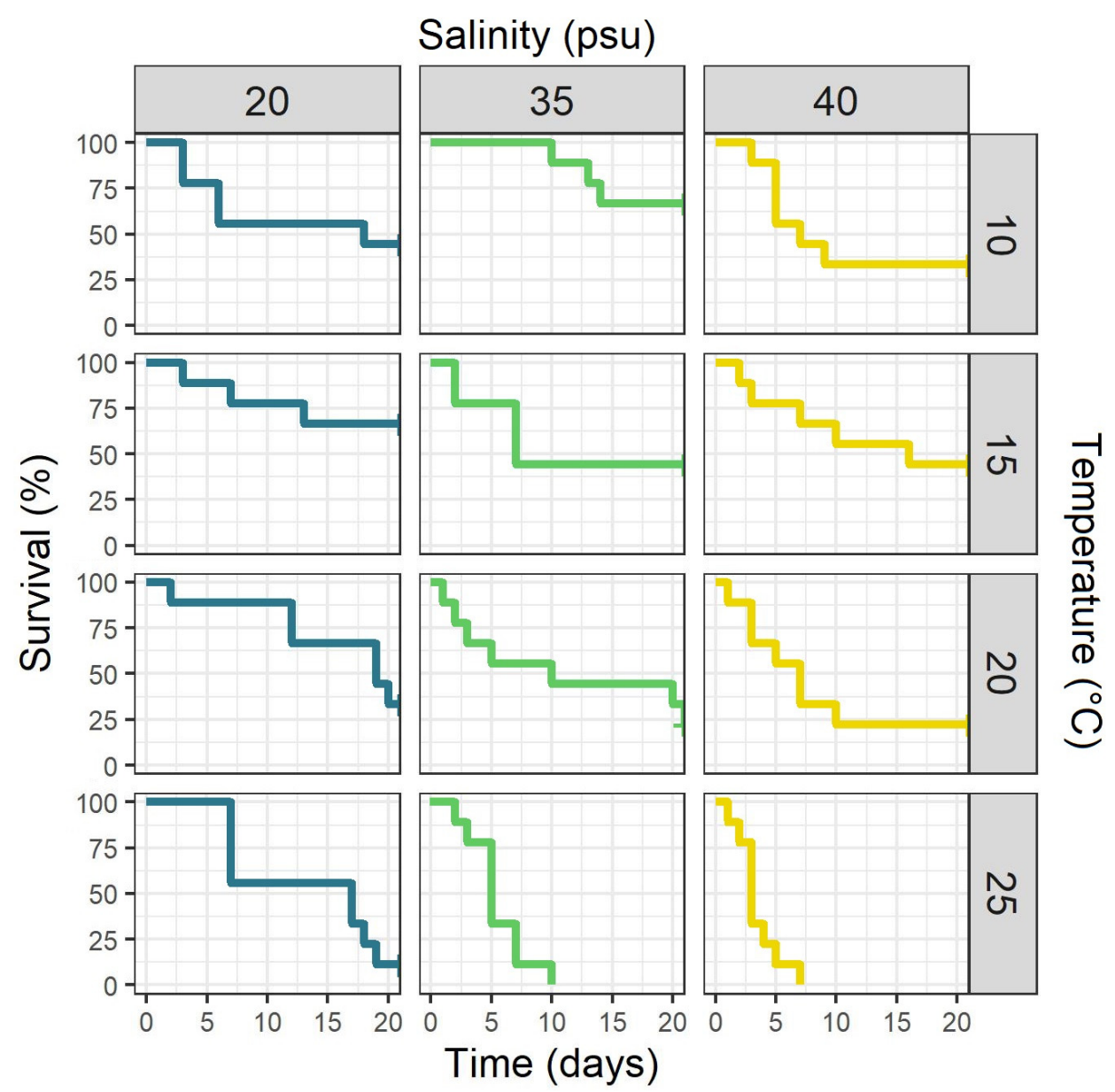

Figure 4. Kaplan-Meier survival curves for Aurelia solida ephyrae that were kept at twelve different combinations of temperatures and salinities over 21 days of the experiment ( $n=9$ per combination). 


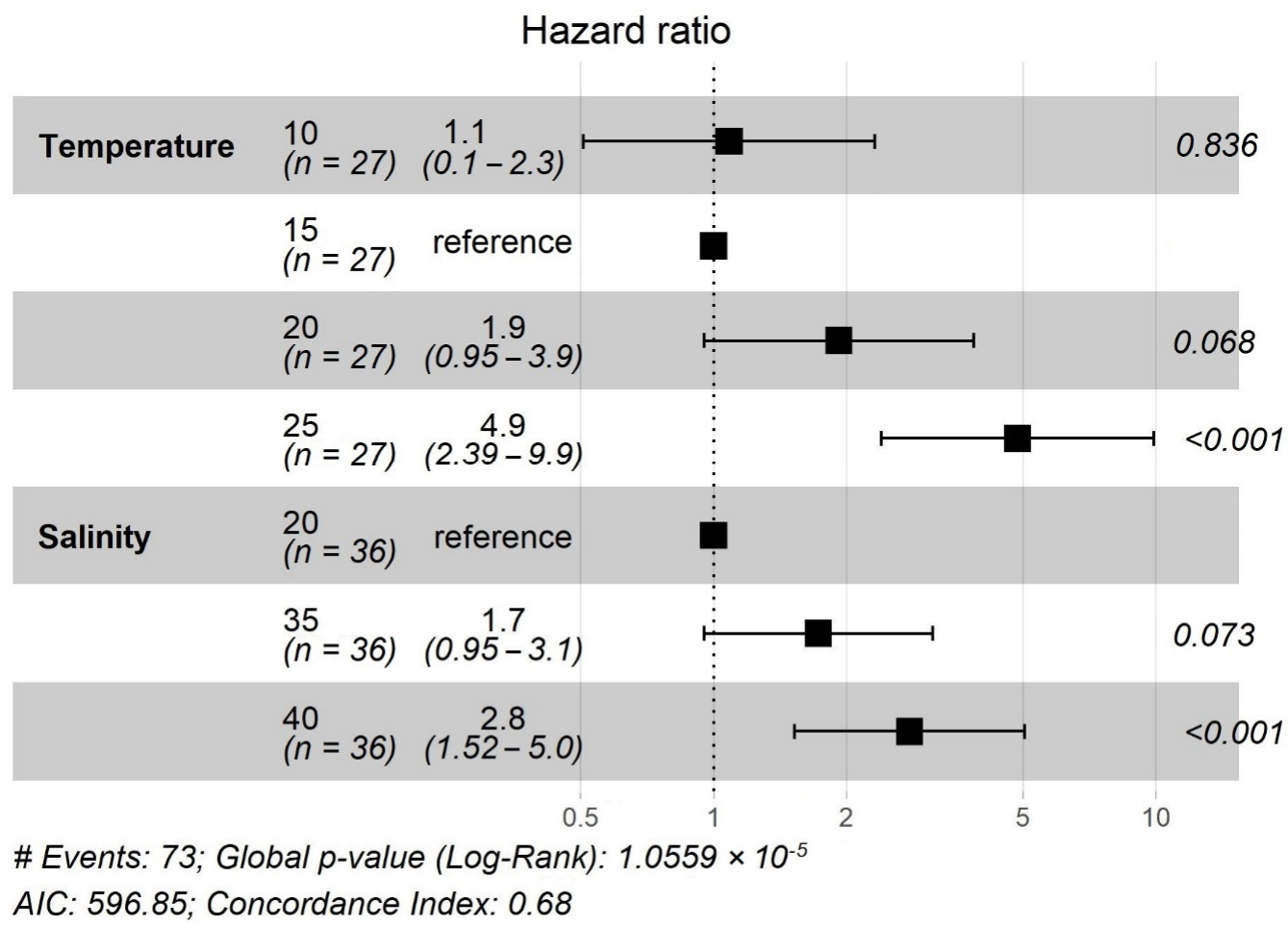

Figure 5. Hazard ratios of Aurelia solida ephyrae that were kept at twelve different combinations of temperatures and salinities over 21 days of the experiment ( $n=9$ per combination). Numbers and horizontal bars represent the ratio and the $95 \%$ confidence interval, respectively. $p$-values display statistical differences between each group and the reference group $\left(15^{\circ} \mathrm{C}\right.$ and $20 \mathrm{psu}$, respectively).

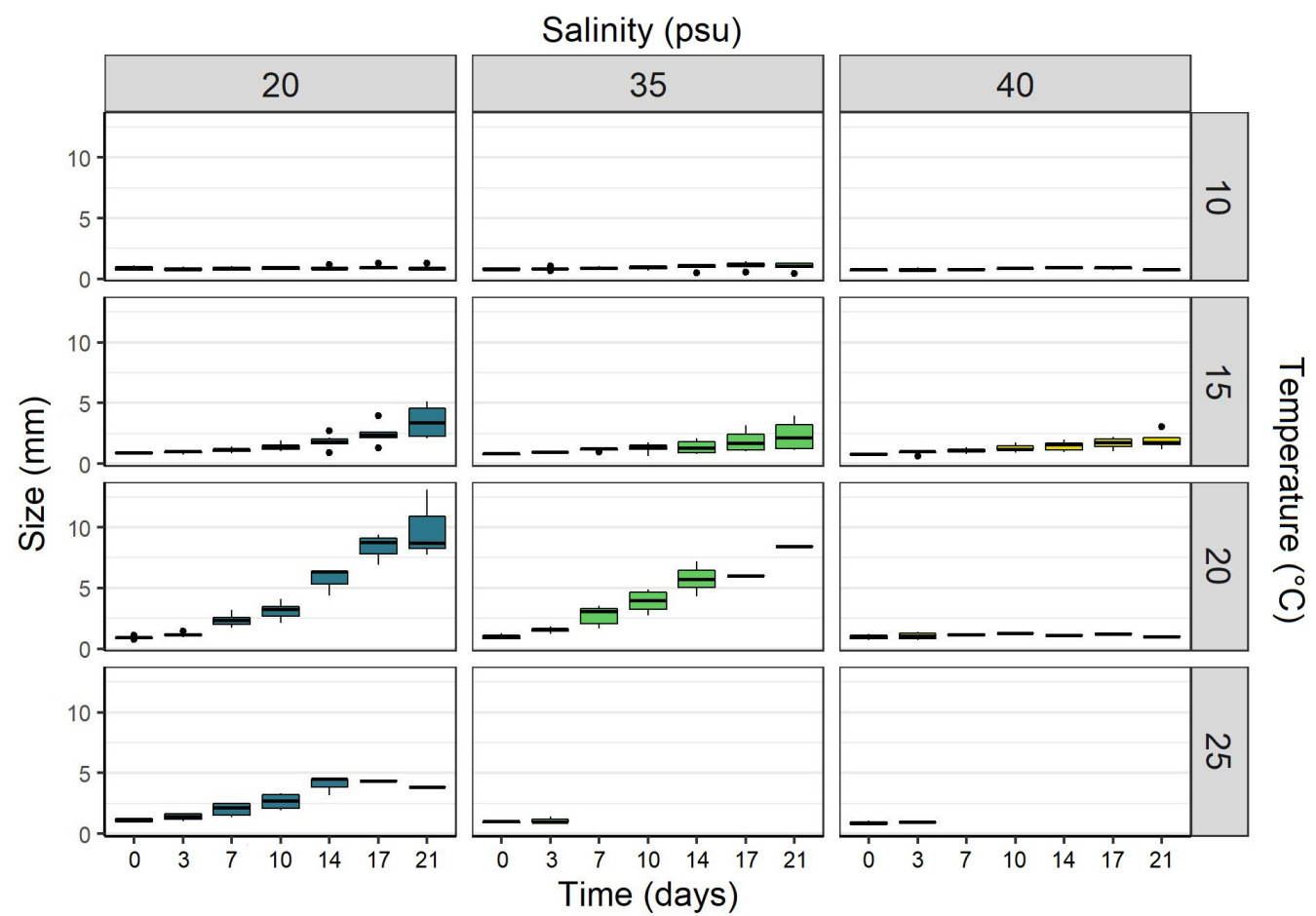

Figure 6. Size (in mm) of Aurelia solida ephyrae that were kept at twelve different combinations of temperatures and salinities over 21 days of the experiment ( $n=9$ per combination). Values are presented as boxplots including quartiles (box and whiskers), median (horizontal line), and outliers (points). 
Finally, ephyra growth rates were highest in the $20{ }^{\circ} \mathrm{C} / 20$ psu treatment, with the ephyrae increasing their size by about sixfold over the course of the three weeks of the experiment (Figure 7). The lowest growth rate of $5.3 \pm 10.4 \%$ occurred in the combination of $10^{\circ} \mathrm{C} / 40 \mathrm{psu}$. Statistical analysis revealed that temperature alone and its interaction with salinity had a significant impact on the growth of the ephyrae (Table 1 and Supplementary Table S2).

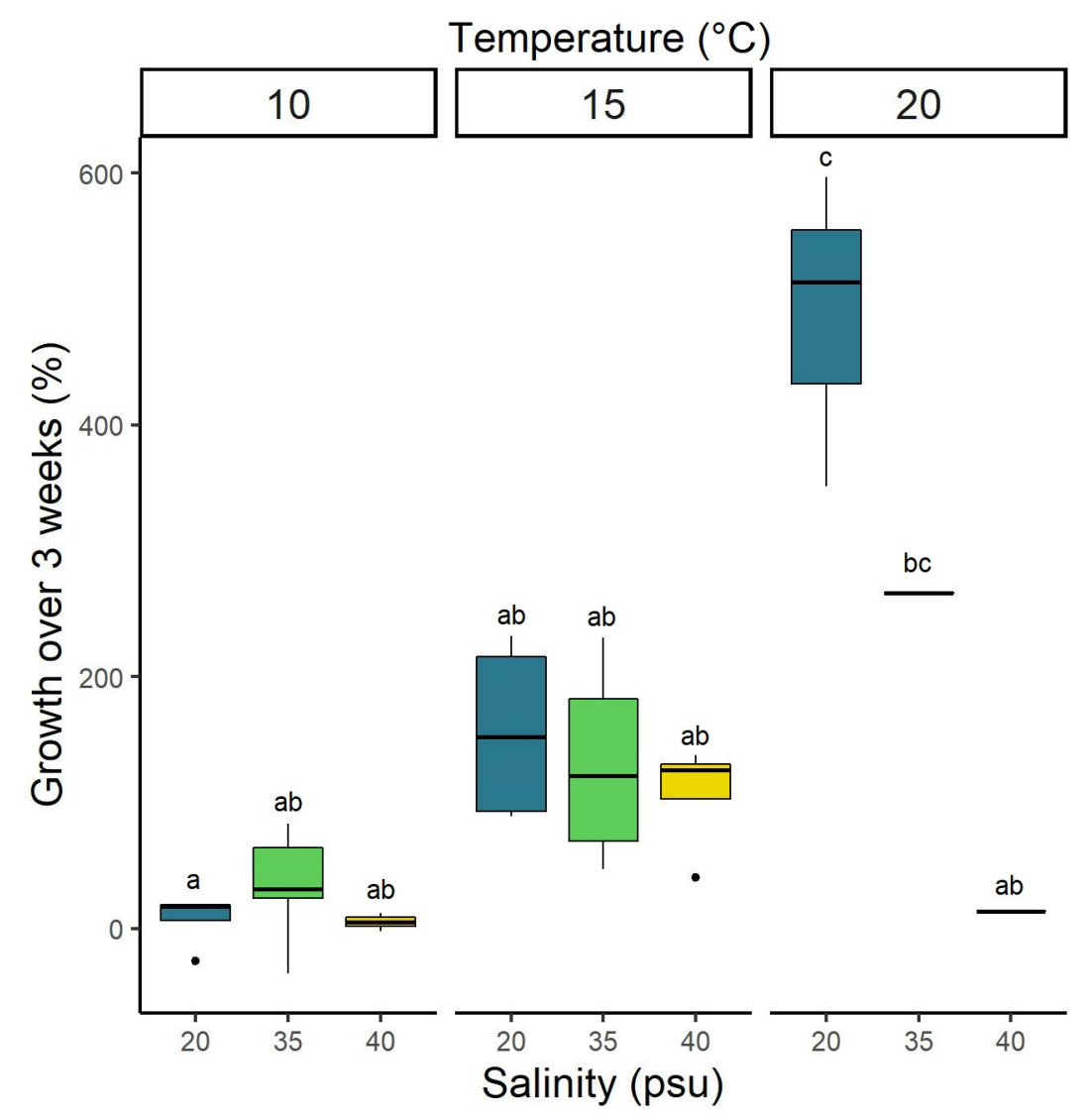

Figure 7. Growth (in \%) of Aurelia solida ephyrae that were kept at twelve different combinations of temperatures and salinities over 21 days of the experiment ( $n=9$ per combination). Values are presented as boxplots including quartiles (box and whiskers), median (horizontal line), and outliers (points). Letters above the boxplots indicate groups identified by Tukey's HSD post-hoc test.

\section{Discussion}

In the present study, A. solida showed high tolerance in life history and physiological responses when exposed to different temperature and salinity regimes. Both parameters individually and/or combined had significant effects on the polyps' survival and asexual reproduction and on the ephyrae's survival and somatic growth. Aurelia solida polyp survival was generally high in most tested temperature and salinity combinations. The only treatment that polyps could not cope with was the highest temperature and lowest salinity $\left(28^{\circ} \mathrm{C} / 20 \mathrm{psu}\right)$, which is a condition that is highly unlikely to occur in their natural environment and was only included in the experiment to ensure a fully crossed design and determine environmental thresholds. The high survival rates in all the other treatments showcase the high adaptability of this species to a wide variety of habitat conditions. This high tolerance has been observed in other Aurelia species polyps, including A. coerulea (9-24 ${ }^{\circ} \mathrm{C}$ and 25-40 psu) [20] and A. aurita s.1. (8-25 ${ }^{\circ} \mathrm{C}$ and $15-35 \mathrm{psu}$ ) [47] (Table 3). However, both species' survival decreased when salinity dropped to 15 psu or below, in combination with either high temperatures $(A$. coerulea) or low temperatures $(A$. aurita s.l.). In the work of Pascual et al. [48], Aurelia polyps originating from the Red Sea and later identified as A. solida [25] showed only $50 \%$ survival at $14{ }^{\circ} \mathrm{C}(38 \mathrm{psu})$, while a high 
survival rate was obtained at $21^{\circ} \mathrm{C}(87 \%)$ and $28^{\circ} \mathrm{C}(70 \%)$. These results contrast with the present study, where polyps at 37 psu never dropped below $92 \%\left(24^{\circ} \mathrm{C}\right)$.

Table 3. Comparison of optimal temperature and salinity conditions for polyp and ephyra survival and asexual reproduction and ephyra growth in different Aurelia species, based on literature.

\begin{tabular}{|c|c|c|c|c|c|c|}
\hline Stage & Parameter & Species & Temperature $\left({ }^{\circ} \mathrm{C}\right)$ & Salinity (psu) & Optimal Combination & Ref \\
\hline \multirow[t]{8}{*}{ Polyp } & Survival & A. aurita * & $14-28$ & 38 & all & [48] \\
\hline & & A. aurita & $4-23$ & $21-34$ & all & {$[22]$} \\
\hline & & A. aurita s.l. & $7.9-25.1$ & $15-35$ & all, except $25^{\circ} \mathrm{C} /<27 \mathrm{psu}$ & [47] \\
\hline & & A. aurita s.l. & $14-28$ & 38 & all & [48] \\
\hline & & A. coerulea & $9-24$ & $15-40$ & all, except $<15^{\circ} \mathrm{C} / 15 \mathrm{psu}$ & [20] \\
\hline & & A. labiata & $7-15$ & $20-34$ & all (but lower at $7^{\circ} \mathrm{C} / 34 \mathrm{psu}$ ) & [23] \\
\hline & & A. solida * & $14-28$ & 38 & all (but lower at $14^{\circ} \mathrm{C}$ ) & [48] \\
\hline & & A. solida & $12-28$ & $20-40$ & all, except $28^{\circ} \mathrm{C} / 20 \mathrm{psu}$ & $* *$ \\
\hline \multirow[t]{10}{*}{ Polyp } & Budding & A. aurita * & $14-28$ & 38 & $28^{\circ} \mathrm{C} / 38 \mathrm{psu}$ & [48] \\
\hline & & A. aurita & $4-23$ & $21-34$ & $9^{\circ} \mathrm{C} / 21 \mathrm{psu}$ & [22] \\
\hline & & A. aurita s.l. & $7.9-25.1$ & $15-35$ & $17.4^{\circ} \mathrm{C} / 3 \mathrm{psu}$ & [47] \\
\hline & & A. aurita s.l. & $14-28$ & 38 & $28^{\circ} \mathrm{C} / 38 \mathrm{psu}$ & [48] \\
\hline & & A. coerulea & $9-24$ & $15-40$ & $21^{\circ} \mathrm{C} / 25 \mathrm{psu}$ & [20] \\
\hline & & A. coerulea & 14 and 21 & 24 and 37 & $14{ }^{\circ} \mathrm{C} / 24 \mathrm{psu}$ & [49] \\
\hline & & A. labiata & $7-15$ & $20-34$ & $7^{\circ} \mathrm{C} / 27 \mathrm{psu}$ & [23] \\
\hline & & A. relicta & 14 and 21 & 37 & $14^{\circ} \mathrm{C} / 37 \mathrm{psu}$ & [49] \\
\hline & & A. solida * & $14-28$ & 38 & $28^{\circ} \mathrm{C} / 38 \mathrm{psu}$ & [48] \\
\hline & & A. solida & $12-28$ & $20-40$ & $20{ }^{\circ} \mathrm{C} / 30 \mathrm{psu}$ & $* *$ \\
\hline \multirow[t]{7}{*}{ Polyp } & Strobilation & A. aurita * & $14-28$ & 38 & $14{ }^{\circ} \mathrm{C} / 38 \mathrm{psu}$ & [48] \\
\hline & & A. aurita & $4-23$ & $21-34$ & $4^{\circ} \mathrm{C} / 27 \mathrm{psu}$ & [22] \\
\hline & & A. aurita s.l. & $14-28$ & 38 & $14^{\circ} \mathrm{C} / 38 \mathrm{psu}$ & [48] \\
\hline & & A. coerulea & $9-24$ & $15-40$ & $15^{\circ} \mathrm{C} / 33$ psu & [20] \\
\hline & & A. labiata & $7-15$ & $20-34$ & $15^{\circ} \mathrm{C} / 27 \mathrm{psu}$ & [23] \\
\hline & & A. solida * & $14-28$ & 38 & $14{ }^{\circ} \mathrm{C} / 38$ psu & [48] \\
\hline & & A. solida & $12-28$ & $20-40$ & $16{ }^{\circ} \mathrm{C} / 35 \mathrm{psu}$ & $* *$ \\
\hline \multirow[t]{3}{*}{ Ephyra } & Survival & A. aurita & $6-18$ & 35 & all & [50] \\
\hline & & & 18 & $17.5-35$ & all & \\
\hline & & A. solida & $10-25$ & $20-40$ & $\begin{array}{c}15^{\circ} \mathrm{C} / 20 \mathrm{psu} \text { and } \\
10^{\circ} \mathrm{C} / 35 \mathrm{psu}\end{array}$ & $* *$ \\
\hline \multirow{5}{*}{ Ephyra } & & & $6-18$ & 35 & $18^{\circ} \mathrm{C} / 35 \mathrm{psu}$ & [50] \\
\hline & Growth & A. aurita & 18 & $17.5-35$ & $18^{\circ} \mathrm{C} / 35 \mathrm{psu}$ & [50] \\
\hline & & A. coerulea & $10-25$ & $22-31$ & $25^{\circ} \mathrm{C} / 25 \mathrm{psu}$ & [51] \\
\hline & & A. labiata & $8-28$ & 34 & $21^{\circ} \mathrm{C} / 34 \mathrm{psu}$ & [52] \\
\hline & & A. solida & $10-25$ & $20-40$ & $20{ }^{\circ} \mathrm{C} / 20 \mathrm{psu}$ & $* *$ \\
\hline
\end{tabular}

* Authors studied A. aurita s.l. populations from the Baltic, Mediterranean, and Red Sea which were later identified as A. aurita (Baltic Sea) and A. solida (Red Sea) by Scorrano et al. [28]; ${ }^{* *}$ the present study.

The diversity of the Aurelia genus is coupled with a large range of variability in the optimum conditions for growth (Table 3). The ideal temperature for asexual reproduction (excluding strobilation) ranges from $7{ }^{\circ} \mathrm{C}$ and $9{ }^{\circ} \mathrm{C}$ for A. labiata [23] and A. aurita [22], over $14^{\circ} \mathrm{C}$ for $A$. relicta [49], $2{ }^{\circ} \mathrm{C}$ for $A$. coerulea [20], and up to $28^{\circ} \mathrm{C}$ for $A$. solida [48]. However, comparing our results with the sole other study investigating temperature effects on A. solida (originating from the Red Sea) [48] shows differences in responses. Although both polyp populations exhibited similar individual daily budding rates $(0.34$ and 0.36 in [48] and the present study, respectively) at $28^{\circ} \mathrm{C}$ and similar salinity (37-38 psu), the highest asexual reproduction was observed at different temperatures: $28{ }^{\circ} \mathrm{C}$ in the work of Pascual et al. [48] and $20^{\circ} \mathrm{C}$ in the present study. Moreover, we demonstrated that the peak of $A$. solida budding rate $(0.92)$ was achieved at a lower temperature $\left(20^{\circ} \mathrm{C}\right)$ and salinity ( $30 \mathrm{psu}$ ) - a more estuary-like condition. These differences might be due to differences in experimental protocols (acclimation) or the different origins of the polyps used in both studies. Populations from different origins often show adaptations to their local environment (genetic or phenotypic plasticity) [53-55]. 
In contrast, the optimum salinity seems more restricted in Aurelia polyps, ranging from 21 to $30 \mathrm{psu}$ (A. aurita s.l. in [22] and A. solida in the present study, Table 3 ). This shows that Aurelia polyps prefer slightly brackish conditions over fully marine. Our results contrast with previous suggestions that $A$. solida displays an ecophysiological preference for stable Mediterranean open sea conditions rather than the semi-enclosed brackish ecosystem with fluctuating states [28]. One of the well-established $A$. solida populations in the Mediterranean Sea is in the Bizerte Lagoon [28], where temperature $\left(11-28{ }^{\circ} \mathrm{C}\right)$ and salinity (20-40 psu) display considerable inter-annual and inter-monthly variations $[31,32,34]$.

The results of strobilation in $A$. solida (highest at $16^{\circ} \mathrm{C}$ and $35 \mathrm{psu}$ ) are very similar to some other Aurelia species, showing similar subtropical affinities to those of $A$. coerulea (most ephyrae at $15^{\circ} \mathrm{C}$ and $33 \mathrm{psu}$ ) [20] and A. labiata (most strobiles and ephyrae at $15^{\circ} \mathrm{C}$ and 27 psu; [23], Table 3). On the other side, $A$. aurita, considered to be a species with more boreal affinity, showed the highest ephyra production at $4^{\circ} \mathrm{C}$ and $27 \mathrm{psu}$ [22]. In the present study, most of the strobilation was recorded at $16{ }^{\circ} \mathrm{C}-$ a temperature slightly higher than the ones recorded in the Adriatic Sea $\left(8-15^{\circ} \mathrm{C}\right)$ [30] and the Bizerte Lagoon $\left(11.4-15^{\circ} \mathrm{C}\right.$; [28], Gueroun, personal communication) when ephyrae and/or strobiles occurred, but close to the condition recorded in the Red Sea [29]. In the Red Sea, A. solida (mentioned as $A$. aurita) [29] occurred the whole year, but ephyrae were only observed in December and January when the temperature was around $17^{\circ} \mathrm{C}$ [29]. The absence of ephyrae during the other months suggests that high temperature in the Red Sea during this period $\left(18-31^{\circ} \mathrm{C}\right)$ is not appropriate for strobilation. However, Pascual et al. [48] showed that polyps were able to produce ephyrae at higher temperatures-21 and $28{ }^{\circ} \mathrm{C}$ (salinity $38 \mathrm{psu}$ )—although the number of polyps undergoing the strobilation process was limited $\left(6 \%\right.$ at $28{ }^{\circ} \mathrm{C}$ and $12 \%$ at $\left.21{ }^{\circ} \mathrm{C}\right)$. For all the cases, experimental and in situ, lower temperatures $\left(\leq 16{ }^{\circ} \mathrm{C}\right)$ were the trigger for A. solida strobilation onset ([28-30,48], present study).

The initial cases of ephyra mortality in almost all combinations of variables were most likely still remainders from the acclimation to the different conditions. In some combinations, individual ephyrae underwent such a rapid increase in size that the setup might have limited their growth and, consequently, survival in the final week of the experiment. The growth study's main objective was to evaluate the initial growth of newly hatched ephyrae; therefore, the setup focused on accommodating this size class and their needs. The ephyrae showed typical exponential growth during the first part of their development [17]. At $20{ }^{\circ} \mathrm{C} / 20-35 \mathrm{psu}$ and $25^{\circ} \mathrm{C} / 20 \mathrm{psu}$, the ephyrae showed fast and good development over the first two weeks. Nonetheless, some ephyrae's umbrellas started to decrease over the third week, while the oral arms inflated for unknown reasons. This could have potentially resulted from the size increase of the ephyrae and the bubbling/movement in the enclosures not being sufficient to keep the animals suspended.

Studies on other Aurelia species showed similar results for the optimal temperatures for growth. Aurelia aurita, A. labiata, and A. coerulea reached their highest growth rates at $18{ }^{\circ} \mathrm{C}$, $21{ }^{\circ} \mathrm{C}$, and $25^{\circ} \mathrm{C}$, respectively [50-52] (Table 3). Furthermore, the study of Fu et al. [51] on A. coerulea showed that, similarly to our experiment, a reduced salinity ( $25 \mathrm{psu}$ ) resulted in slightly higher growth rates. Considering both the results of ephyra survival and growth in the present study, $A$. solida ephyrae reach their optimum at temperatures between 15 and $20^{\circ} \mathrm{C}$ and salinities of $20 \mathrm{psu}$, showing the best combination of high survival and high growth rates. Most responses showed significant effects for the interaction of temperature and salinity, which underlines the importance of running multiparameter experiments to evaluate the impact of fluctuating environmental conditions.

The interaction of temperature and salinity had significant effects on $A$. solida polyp survival and asexual reproduction and ephyra growth rate, suggesting the synergistic effects of both factors on the polyps and early pelagic stage may be as crucial as the individual factors. The tolerance of $A$. solida with respect to different temperatures and salinities is very high, making it a potential inhabitant/invader of a wide range of coastal ecosystems (e.g., bays, estuaries, lagoons). The species could potentially show the highest 
success in regions with temperate/subtropical summers (budding at $20^{\circ} \mathrm{C}$ ) and moderate winters (strobilation at $12-16^{\circ} \mathrm{C}$ ). The high resistance of $A$. solida polyps to a wide range of temperatures and salinities provides a great baseline for this species to endure even less favorable conditions at the polyp stage, using seasons with more suitable conditions for strobilation and entering the cycle of sexual reproduction.

Most Aurelia species require cold winter temperatures to complete their asexual life cycle. A study from Loveridge et al. [56] tested scenarios of warmer winters on A. aurita and found that the polyps need a minimum period of winter temperatures to induce significant strobilation $\left(\geq 6\right.$ weeks at $\leq 7^{\circ} \mathrm{C}$ ). Therefore, warmer winter conditions under future climate change could significantly reduce ephyra production and eventually inhibit it altogether. In the case of $A$. solida, this study showed that the polyps strobilated at higher temperatures and without a previous cold shock/winter. In the Bizerte Lagoon, Tunisia, the temperature varies from 11 to $28{ }^{\circ} \mathrm{C}$ and the salinity varies from 22 to $38 \mathrm{psu}$ [32]. However, lately, temperatures are rising, and winter temperatures inside the lagoon did not fall below $13{ }^{\circ} \mathrm{C}$ in some years, with an average of around $14.2 \pm 0.9{ }^{\circ} \mathrm{C}$ (Gueroun, personal communication). Therefore, the local population of $A$. solida might increase over the following decades due to increasing winter temperatures approaching optimal conditions for strobilation $\left(16^{\circ} \mathrm{C}\right)$. The Aurelia populations in the Adriatic Sea (Mediterranean Sea) face average temperatures from 12 up to $25^{\circ} \mathrm{C}$ in summers [57]. With ongoing warming, this seasonal range is predicted to shift to warmer temperatures by $+3.8^{\circ} \mathrm{C}$ per century, but with winter temperatures shifting at a much slower rate $\left(+0.7^{\circ} \mathrm{C} /\right.$ century $)$ [57]. The north of the Adriatic is peculiarly highly influenced by the freshwater discharge of several main rivers; salinity can therefore vary greatly (mainly 30-39 psu, but some locations with much lower salinities) [58]. Considering the results of the present study regarding the tolerance and optimal conditions for $A$. solida survival, growth, and strobilation, populations in the Adriatic Sea should be able to face ongoing changes over the upcoming decades. Populations in the area might benefit from slightly increasing winter temperatures, pushing the temperatures closer to their strobilation optimum $\left(16^{\circ} \mathrm{C}\right.$, present study). However, even if $A$. solida could benefit under climate change initially, the specific characteristics of the Adriatic Sea might eventually determine the population's fate. Indeed, Canning-Clode and Carlton [59] have described the northern Adriatic Sea as a "range termini" with very limited escape routes. It was pointed out that in the case of the Adriatic Sea, poleward range expansions are limited by the southern European coast as a geographic barrier that leaves species with very limited escape routes (e.g., human mediated transport) [59]. While rising temperature is often presented as a booster for jellyfish proliferation (until a certain point), the role of salinity should not be neglected. In the case of $A$. solida, the potential benefit of rising temperature might be buffered by the increase of salinity in the Mediterranean Sea [60].

Climate change and increased marine traffic might benefit various jellyfish species through spatial translocation and driving phenology shifts and bloom events [61-63]. When suitable conditions, including temperature and salinity, are met during the polyp and ephyra stages, jellyfish blooms occur. These blooms have significant consequences on the trophic web through direct predatory pressure and indirect cascading effects caused by post-bloom body decomposition and subsequent release of nutrients and dissolved organic matter [64,65]. Studies on the specific impacts of $A$. solida blooms on ecosystems are still scarce. However, $A$. solida has been shown to ingest already up to $39 \%$ of the daily zooplankton standing stock at current high abundance levels [28]. The occurrence of long blooms could, therefore, drastically impact the local community's structure and function. Furthermore, bacteria associated with $A$. solida might substantially affect the trophic web [66] after its decomposition and can function as a host to transfer bacteria to higher trophic levels [67,68].

The present study determined the optimal temperature and salinity ranges that provide the best performance and survival of $A$. solida and uncovered its high tolerance capacity. These insights on its ecology build a baseline to compare studies of different regions/populations and help to put the future of $A$. solida under ongoing climate change 
into perspective. Furthermore, it underlines the need for physiological tolerance studies covering a broad scale of parameters and their interaction. However, these kinds of studies have only a limited application/usability if the species is not well identified, leading to possibly false predictions on the future development of the population. In the case of the Aurelia genus, the limitations of previous studies have been confirmed and need to be revised or addressed with caution. In the light of the $A$. solida identification in the Mediterranean Sea, several questions arise in relation to previous research. In the Bizerte Lagoon, the first records of the genus Aurelia date back to 1994 [69]. In the following years, the scyphomedusa was never mentioned and visually absent [35] until 2012 ([28,32,70], Gueroun, personal communication). Was A. solida the initially recorded species, or did it replace the 1990s species? Is the drastic shift recorded in the Aurelia sp. dynamics in the NE Adriatic Sea [71] and Bizerte Lagoon [35] a consequence of a previous Aurelia sp. replacement by $A$. solida or a result of more suitable environmental conditions? In a more global range, do the different established $A$. solida populations present the same ecological characteristics?

Undoubtedly, future research on A. solida and other cryptic Aurelia species will need to address these questions in order to understand the ecology of each species and predict the different populations' possible responses and impact on ecosystems in the context of climate change.

Supplementary Materials: The following are available online at https://www.mdpi.com/article/ 10.3390/d13110573/s1. Table S1: Statistical analysis for the asexual reproduction of Aurelia solida polyps kept under several combinations of different temperatures and salinities. Results of posthoc pairwise Tukey Tests with significant differences indicated by different letters (a-k). Table S2: Statistical analysis for the growth of Aurelia solida ephyrae kept under several combinations of different temperatures and salinities. Results of post-hoc Tukey's HSD test. Significant results $(p<0.05)$ are highlighted in bold.

Author Contributions: Conceptualization, S.S. and S.K.M.G.; methodology, S.S. and S.K.M.G.; formal analyses and investigation, S.S.; writing — original draft preparation, S.S. and S.K.M.G.; writingreview and editing, S.S., S.K.M.G., C.A., and J.C.-C.; funding acquisition, C.A. and J.C.-C. All authors have read and agreed to the published version of the manuscript.

Funding: This work was funded by the project Gojelly-A gelatinous solution to plastic pollutionfrom the European Union's Horizon 2020 research and innovation program (grant agreement No. 774499). This study also had the support of Fundação para a Ciência e Tecnologia (FCT), through the strategic project (UIDB/04292/2020) granted to MARE UI\&I. JCC is funded by national funds through FCT—Fundação para a Ciência e a Tecnologia, I.P., under the Scientific Employment StimulusInstitutional Call-[CEECINST/00098/2018].

Institutional Review Board Statement: Not applicable.

Data Availability Statement: Datasets generated and/or analyzed during the current study are available from the corresponding author on reasonable request. The data are not publicly available as the present study is still part of an ongoing project.

Acknowledgments: We thank Vienna Zoo for providing the Aurelia solida polyps. Furthermore, we would like to thank Tiago Marques, Clara Cordeiro, and Marc Fernandez for their valuable comments on the statistical analysis performed in this study.

Conflicts of Interest: The authors declare no conflict of interest.

\section{References}

1. Graham, W.M.; Gelcich, S.; Robinson, K.L.; Duarte, C.M.; Brotz, L.; Purcell, J.E.; Madin, L.P.; Mianzan, H.; Sutherland, K.R.; Uye, S.; et al. Linking human well-being and jellyfish: Ecosystem services, impacts, and societal responses. Front. Ecol. Environ. 2014, 12, 515-523. [CrossRef]

2. Tilves, U.; Purcell, J.E.; Fuentes, V.L.; Torrents, A.; Pascual, M.; Raya, V.; Gili, J.-M.; Sabates, A. Natural diet and predation impacts of Pelagia noctiluca on fish eggs and larvae in the NW Mediterranean. J. Plankton Res. 2016, 38, 1243-1254. [CrossRef] 
3. Milisenda, G.; Rosa, S.; Fuentes, V.L.; Boero, F.; Guglielmo, L.; Purcell, J.E.; Piraino, S. Jellyfish as prey: Frequency of predation and selective foraging of Boops boops (Vertebrata, Actinopterygii) on the mauve stinger Pelagia noctiluca (Cnidaria, Scyphozoa). PLOS ONE 2014, 9, e94600. [CrossRef]

4. Sweetman, A.K.; Smith, C.R.; Dale, T.; Jones, D.O.B. Rapid scavenging of jellyfish carcasses reveals the importance of gelatinous material to deep-sea food webs. Proc. R. Soc. B 2014, 281, 20142210. [CrossRef] [PubMed]

5. Chelsky, A.; Pitt, K.A.; Ferguson, A.J.P.; Bennett, W.W.; Teasdale, P.R.; Welsh, D.T. Decomposition of jellyfish carrion in situ: Short-term impacts on infauna, benthic nutrient fluxes and sediment redox conditions. Sci. Total Environ. 2016, 566-567, 929-937. [CrossRef]

6. Ruzicka, J.J.; Daly, E.A.; Brodeur, R.D. Evidence that summer jellyfish blooms impact Pacific Northwest salmon production. Ecosphere 2016, 7, 7. [CrossRef]

7. Pitt, K.A.; Lucas, C.H.; Condon, R.H.; Duarte, C.M.; Stewart-Koster, B. Claims That Anthropogenic Stressors Facilitate Jellyfish Blooms Have Been Amplified Beyond the Available Evidence: A Systematic Review. Front. Mar. Sci. 2018, 5, 5. [CrossRef]

8. Purcell, J.E.; Uye, S.; Lo, W.-T. Anthropogenic causes of jellyfish blooms and their direct consequences for humans: A review. Mar. Ecol. Prog. Ser. 2007, 350, 153-174. [CrossRef]

9. Bosch-Belmar, M.; Milisenda, G.; Basso, L.; Doyle, T.K.; Leone, A.; Piraino, S. Jellyfish Impacts on Marine Aquaculture and Fisheries. Rev. Fish. Sci. Aquac. 2020, 29, 242-259. [CrossRef]

10. Ghermandi, A.; Galil, B.; Gowdy, J.; Nunes, P.A.L.D. Jellyfish outbreak impacts on recreation in the Mediterranean Sea: Welfare estimates from a socioeconomic pilot survey in Israel. Ecosyst. Serv. 2015, 11, 140-147. [CrossRef]

11. Lucas, C.H.; Gelcich, S.; Uye, S.-I. Living with jellyfish: Management and adaptation strategies. In Jellyfish Blooms; Springer: Cham, Switzerland, 2014; pp. 129-150. [CrossRef]

12. Masilamoni, J.G.; Jesudoss, K.S.; Nandakumar, K.; Satpathy, K.K.; Nair, K.V.K.; Azariah, J. Jellyfish ingress: A threat to the smooth operation of coastal power plants. Curr. Sci. 2000, 79, 567-569.

13. Dong, Z. Blooms of the Moon Jellyfish Aurelia: Causes, Consequences and Controls. In World Seas: An Environmental Evaluation; Elsevier: Amsterdam, The Netherlands, 2019; pp. 163-171. [CrossRef]

14. Miyajima-Taga, Y.; Masuda, R.; Kurihara, A.; Yamashita, Y.; Takeuchi, T. Feeding moon jellyfish improves the tilting behavior of hatchery-reared red sea bream juveniles. Nippon. Suisan Gakkaishi 2014, 80, 934-945. [CrossRef]

15. Khong, N.M.H.; Yusoff, F.M.; Jamilah, B.; Basri, M.; Maznah, I.; Chan, K.W.; Nishikawa, J. Nutritional composition and total collagen content of three commercially important edible jellyfish. Food Chem. 2016, 196, 953-960. [CrossRef] [PubMed]

16. Leone, A.; Marina, R.; Giacomo, L.; Piraino, S. Mediterranean jellyfish as novel food: Effects of thermal processing on antioxidant, phenolic, and protein contents. Eur. Food Res. Technol. 2019, 245, 1611-1627. [CrossRef]

17. Arai, M.N. A Functional Biology of Scyphozoa; Springer Science and Business Media: Cham, Switzerland, 1997.

18. Kienberger, K.; Riera-Buch, M.; Schönemann, A.M.; Bartsch, V.; Halbauer, R.; Prieto, L. First description of the life cycle of the jellyfish Rhizostoma luteum (Scyphozoa: Rhizostomeae). PLoS ONE 2018, 13, e0202093. [CrossRef] [PubMed]

19. Schiariti, A.; Morandini, A.C.; Jarms, G.; Paes, R.V.G.; Franke, S.; Mianzan, H. Asexual reproduction strategies and blooming potential in Scyphozoa. Mar. Ecol. Prog. Ser. 2014, 510, 241-253. [CrossRef]

20. Yongze, X.; Qian, L.; Mei, Z.; Yu, Z.; Tiezhu, M.; Zhigang, Y. Effects of temperature and salinity on the asexual reproduction of Aurelia coerulea polyps. J. Oceanol. Limnol. 2020, 38, 133-142. [CrossRef]

21. Pitt, K.A.; Kingsford, M.J. Reproductive biology of the edible jellyfish Catostylus mosaicus (Rhizostomeae). Mar. Biol. 2000, 137, 791-799. [CrossRef]

22. Widmer, C.L.; Fox, C.J.; Brierley, A.S. Effects of temperature and salinity on four species of north-eastern Atlantic scyphistomae (Cnidaria: Scyphozoa). Mar. Ecol. Prog. Ser. 2016, 559, 73-88. [CrossRef]

23. Purcell, J.E. Environmental effects on asexual reproduction rates of the scyphozoan Aurelia labiata. Mar. Ecol. Prog. Ser. 2007, 348, 183-196. [CrossRef]

24. Dawson, M.N.; Jacobs, D.K. Molecular Evidence for Cryptic Species of Aurelia aurita (Cnidaria, Scyphozoa). Biol. Bull. 2001, 200, 92-96. [CrossRef]

25. Scorrano, S.; Aglieri, G.; Boero, F.; Dawson, M.N.; Piraino, S. Unmasking Aurelia species in the Mediterranean Sea: An integrative morphometric and molecular approach. Zool. J. Linn. Soc. 2017, 180, 243-267. [CrossRef]

26. Kramp, P.L. Synopsis of the medusae of the world. J. Mar. Biol. Assoc. United Kingd. 1961, 40, 7-382. [CrossRef]

27. Gueroun, S.K.M.; Javidpour, J.; Andrade, C.; Nogueira, N.; Freitas, M.; Canning-Clode, J. Pelagic Cnidaria and Ctenophora diversity patterns and trends in Macaronesia insular systems (NE Atlantic). Mar. Biodivers. 2021, 51, 1-13. [CrossRef]

28. Gueroun, S.K.M.; Molinero, J.C.; Piraino, S.; Daly Yahia, M.N. Population dynamics and predatory impact of the alien jellyfish Aurelia solida (Cnidaria, Scyphozoa) in the Bizerte Lagoon (southwestern Mediterranean Sea). Mediterr. Mar. Sci. 2020, 21, 22-35. [CrossRef]

29. El-Serehy, H.A.; Al-Rasheid, K.A. Reproductive strategy of the jellyfish Aurelia aurita (Cnidaria Scyphomedusae) in the Suez Canal and its migration between the Red Sea and Mediterranean. Aquat. Ecosyst. Health Manag. 2011, 14, 269-275. [CrossRef]

30. Malej, A.; Kogovšek, T.; Ramšak, A.; Catenacci, L. Blooms and population dynamics of moon jellyfish in the northern Adriatic. Cah. Biol. Mar. 2012, 53, 337-342.

31. Afli, A.; Ayari, R.; Zaabi, S. Ecological quality of some Tunisian coast and lagoon locations, by using benthic community parameters and biotic indices. Estuar. Coast. Shelf Sci. 2008, 80, 269-280. [CrossRef] 
32. Gueroun, S.K.M.; Yahia, O.K.-D.; Deidun, A.; Fuentes, V.; Piraino, S.; Daly Yahia, M.N. First record and potential trophic impact of Phyllorhiza punctata (Cnidaria: Scyphozoa) along the north Tunisian coast South Western Mediterranean Sea. Ital. J. Zool. 2015, 82, 95-100. [CrossRef]

33. Wüst, G. On the vertical circulation of the Mediterranean Sea. J. Geophys. Res. 1961, 66, 3261-3271. [CrossRef]

34. Sakka Hlaili, A.; Chikhaoui, M.-A.; El Grami, B.; Hadj Mabrouk, H. Effects of N and P supply on phytoplankton in Bizerte Lagoon (western Mediterranean). J. Exp. Mar. Biol. Ecol. 2006, 333, 79-96. [CrossRef]

35. Touzri, C.; Hamdi, H.; Goy, J.; Yahia, M.N.D. Diversity and distribution of gelatinous zooplankton in the Southwestern Mediterranean Sea. Mar. Ecol. 2012, 1-14. [CrossRef]

36. Ma, X.; Purcell, J.E. Temperature, salinity, and prey effects on polyp versus medusa bud production by the invasive hydrozoan Moerisia lyonsi. Mar. Biol. 2005, 147, 225-234. [CrossRef]

37. Helm, R.R.; Dunn, C.W. Indoles induce metamorphosis in a broad diversity of jellyfish, but not in a crown jelly (Coronatae). PLoS ONE 2017, 12, e0188601. [CrossRef] [PubMed]

38. Schneider, C.A.; Rasband, W.S.; Eliceiri, K.W. NIH Image to ImageJ: 25 years of image analysis. Nat. Methods 2012, 9, 671-675. [CrossRef] [PubMed]

39. Kassambara, A.; Kosinski, M.; Biecek, P. “Survminer": Drawing Survival Curves Using "ggplot2". 2020. Available online: https:/ /CRAN.R-project.org/package=survminer (accessed on 26 November 2020).

40. Therneau, T. "Survival”: A Package for Survival Analysis in R. 2020. Available online: https://CRAN.R-project.org/package= survival (accessed on 14 December 2020).

41. Bolker, B.; R Core Team. "Bbmle”: Tools for General Maximum Likelihood Estimation. 2020. Available online: https / /CRAN.Rproject.org/package=bbmle (accessed on 8 January 2021).

42. Brooks, M.E.; Kristensen, K.; Van Benthem, K.J.; Magnusson, A.; Berg, C.W.; Nielsen, A.; Skaug, H.J.; Mächler, M.; Bolker, B.M. glmmTMB Balances Speed and Flexibility Among Packages for Zero-inflated Generalized Linear Mixed Modeling. R J. 2017, 9 , 378-400. [CrossRef]

43. Wickham, H. “Tidyr": Tidy Messy Data. 2020. Available online: https:/ /CRAN.R-project.org/package=tidyr (accessed on 27 October 2020).

44. R Core Team. R: A Language and Environment for Statistical Computing; R Foundation: Vienna, Austria, 2020; Available online: https:/ / www.R-project.org/ (accessed on 16 March 2020).

45. Fox, J.; Weisberg, S. “Car”: An \{R\} Companion to Applied Regression. 2019. Available online: https://socialsciences.mcmaster. $\mathrm{ca} /$ jfox/Books/Companion/index.html (accessed on 2 November 2020).

46. Lenth, R.V. “Emmeans": Estimated Marginal Means, aka Least-Squares Means. 2020. Available online: https://CRAN.R-project. org / package=emmeans (accessed on 8 January 2021).

47. Amorim, K.; Mattmüller, R.M.; Algueró-Muñiz, M.; Meunier, C.L.; Alvarez-Fernandez, S.; Boersma, M.; Morais, P.; Teodósio, M.A. Winter river discharge may affect summer estuarine jellyfish blooms. Mar. Ecol. Prog. Ser. 2018, 591, 253-265. [CrossRef]

48. Pascual, M.; Fuentes, V.; Canepa, A.; Atienza, D.; Gili, J.-M.; Purcell, J.E. Temperature effects on asexual reproduction of the scyphozoan Aurelia aurita s.l: Differences between exotic (Baltic and Red seas) and native (Mediterranean Sea) populations. Mar. Ecol. 2015, 36, 994-1002. [CrossRef]

49. Hubot, N.; Lucas, C.H.; Piraino, S. Environmental control of asexual reproduction and somatic growth of Aurelia spp. (Cnidaria, Scyphozoa) polyps from the Adriatic Sea. PLoS ONE 2017, 12, e0178482. [CrossRef] [PubMed]

50. Bamstedt, U.; Lane, J.; Martinussen, M.B. Bioenergetics of ephyra larvae of the scyphozoan jellyfish Aurelia aurita in relation to temperature and salinity. Mar. Biol. 1999, 135, 89-98. [CrossRef]

51. Fu, Z.; Li, J.; Wang, J.; Lai, J.; Liu, Y.; Sun, M. Combined Effects of Temperature and Salinity on the Growth and Pulsation of Moon Jellyfish (Aurelia coerulea) Ephyrae. Am. J. Life Sci. 2020, 8, 144-151. [CrossRef]

52. Widmer, C.L. Effects of temperature on growth of north-east Pacific moon jellyfish ephyrae, Aurelia labiata (Cnidaria: Scyphozoa). J. Mar. Biol. Assoc. United Kingd. 2005, 85, 569-573. [CrossRef]

53. Miller, A.D.; Coleman, M.A.; Clark, J.; Cook, R.; Naga, Z.; Doblin, M.A.; Hoffmann, A.A.; Sherman, C.D.H.; Bellgrove, A. Local thermal adaptation and limited gene flow constrain future climate responses of a marine ecosystem engineer. Evol. Appl. 2020, 13, 918-934. [CrossRef] [PubMed]

54. King, N.G.; McKeown, N.J.; Smale, D.A.; Moore, P.J. The importance of phenotypic plasticity and local adaptation in driving intraspecific variability in thermal niches of marine macrophytes. Ecography 2018, 41, 1469-1484. [CrossRef]

55. Mardones, M.L.; Fenberg, P.B.; Thatje, S.; Hauton, C. Intraspecific plasticity and trans-generational adaptation of reproductive traits and early development in a temperate marine neogastropod. Mar. Environ. Res. 2020, 161, 105123. [CrossRef] [PubMed]

56. Loveridge, A.; Lucas, C.H.; Pitt, K.A. Shorter, warmer winters may inhibit production of ephyrae in a population of the moon jellyfish Aurelia Aurita. Hydrobiologia 2021, 848, 739-749. [CrossRef]

57. Shaltout, M.; Omstedt, A. Recent sea surface temperature trends and future scenarios for the Mediterranean Sea. Oceanologia 2014, 56, 411-443. [CrossRef]

58. Simoncelli, S.; Oliveri, P.; Mattia, G.; Myroshnychenko, V. SeaDataCloud Temperature and Salinity Historical Data Collection for the Mediterranean Sea (Version 2). SeaDaraNet 2020. [CrossRef]

59. Canning-Clode, J.; Carlton, J.T. Refining and expanding global climate change scenarios in the sea: Poleward creep complexities, range termini, and setbacks and surges. Divers. Distrib. 2017, 23, 463-473. [CrossRef] 
60. Vargas-Yáñez, M.; García-Martínez, M.C.; Moya, F.; Balbín, R.; López-Jurado, J.L.; Serra, M.; Zuninod, P.; Pascuale, J.; Salat, J. Updating temperature and salinity mean values and trends in the Western Mediterranean: The RADMED project. Prog. Oceanogr. 2017, 157, 27-46. [CrossRef]

61. Purcell, J.E. Climate effects on formation of jellyfish and ctenophore blooms: A review. J. Mar. Biol. Assoc. United Kingd. 2005, 85, 461-476. [CrossRef]

62. Daly Yahia, M.N.; Batistic, W.; Lucic, D.; Fernández de Puelles, M.L.; Licandro, P.; Malej, A.; Molinero, J.; Siokou-Frangou, I.; Zervoudaki, S.; Prieto, L.; et al. Are outbreaks of Pelagia noctiluca (Forskäl, 1771) more frequent in the Mediterranean basin? In Proceedings of the Joint ICES/CIESM Workshop to Compare Zooplankton Ecology and Methodologies between the Mediterranean and the North Atlantic (WKZEM): ICES Cooperative Research Report, Copenhagen, Denmark, 2 February 2010; Volume 300, pp. 8-14.

63. Castro, N.; Ramalhosa, P.; Jiménez, J.; Costa, J.L.; Gestoso, I.; Canning-Clode, J. Exploring marine invasions connectivity in a NE Atlantic Island through the lens of historical maritime traffic patterns. Reg. Stud. Mar. Sci. 2020, 37, 101333. [CrossRef]

64. Pitt, K.A.; Welsh, Æ.D.T.; Condon, R.H. Influence of jellyfish blooms on carbon, nitrogen and phosphorus cycling and plankton production. Hydrobiologia 2009, 616, 133-149. [CrossRef]

65. Guy-Haim, T.; Rubin-Blum, M.; Rahav, E.; Belkin, N.; Silverman, J.; Sisma-Ventura, G. The effects of decomposing invasive jellyfish on biogeochemical fluxes and microbial dynamics in an ultra-oligotrophic sea. Biogeosciences 2020, 17, 5489-5511. [CrossRef]

66. Kramar, M.K.; Tinta, T.; Lučić, D.; Malej, A.; Turk, V. Bacteria associated with moon jellyfish during bloom and post-bloom periods in the Gulf of Trieste (northern Adriatic). PLoS ONE 2019, 14, e0198056. [CrossRef]

67. Delannoy, C.M.J.; Houghton, J.D.R.; Fleming, N.E.C.; Ferguson, H.W. Mauve Stingers (Pelagia noctiluca) as carriers of the bacterial fish pathogen Tenacibaculum maritimum. Aquaculture 2011, 311, 255-257. [CrossRef]

68. Peng, S.; Hao, W.; Li, Y.; Wang, L.; Sun, T.; Zhao, J.; Dong, Z. Bacterial Communities Associated with Four Blooming Scyphozoan Jellyfish: Potential Species-Specific Consequences for Marine Organisms and Humans Health. Front. Microbiol. 2021, 12, 1-16. [CrossRef]

69. Chakroun, F.; Aloui-Bejaouin, N. Invasion d'Aurelia aurita (Cnidaria, Scyphomédusa) dans le lac de Bizerte (Tunisie) au cours de l'été 1994. Ann. Inst. Océanograph. 1995, 71, 67-69.

70. Gueroun, S.K.M. Diversité et Impact des Méduses sur le Réseau Trophique Planctonique des Ecosystèmes Lagunaire et Côtier de la Région de Bizerte. Master's Thesis, Faculty of Science of Bizerte, Carthage University, Bizerte, Tunisia, 2012.

71. Kogovsek, T.; Bogunovic, B.; Malej, A. Recurrence of bloom-forming scyphomedusae: Wavelet analysis of a 200-year time series. Hydrobiologia 2010, 645, 81-96. [CrossRef] 